\title{
Inca Human Sacrifices on Misti Volcano (Peru)
}

\author{
Dagmara M. Socha (D), Johan Reinhard, and Ruddy Chávez Perea
}

\begin{abstract}
One of the most impressive examples of an Inca capacocha ceremony was discovered during an archaeological expedition to the summit of Misti volcano in 1998. The offerings at the site included several human sacrifices, along with fine ceramics and figurines made from gold, silver, and Spondylus sp. shell. One of the two burials appeared to contain the bones of males and the other of females. The sex was established based on the contents of the graves, because the fragile skeletal material had been badly affected by volcanic activity and exact identification was difficult to make in situ. To limit the risk of damage, the bones were excavated together with the surrounding soil and transported in frozen blocks to the Museo Santuarios Andinos of Universidad Católica de Santa María in Arequipa. This material was the object of a bioarchaeological investigation in February and March 2018. The results revealed that at least eight individuals had been buried in the graves. The findings have increased our understanding of the age categories and physical condition of the individuals chosen to be sacrificed during the capacocha ritual.
\end{abstract}

Keywords: Inca, capacocha, Misti, human sacrifices

Uno de los ejemplos más impresionantes de la ceremonia inca capacocha fue descubierto durante una expedición arqueológica a la cumbre del volcán Misti en 1998. Las ofrendas en el sitio incluyeron varios sacrificios humanos, junto con cerámicas finas y figurillas hechas de oro, plata y concha de Spondylus sp. Uno de los entierros parecía contener huesos de individuos masculinos y el otro de individuos femeninos. El sexo se estableció en función del contenido de los entierros, ya que el material esqueletal estaba gravemente afectado por la actividad volcánica y la identificación exacta fue difícil de realizar in situ. Para limitar el riesgo de daños, los huesos fueron excavados junto con el suelo circundante y transportados en bloques congelados al Museo Santuarios Andinos de la Universidad Católica de Santa María en Arequipa. El material fue objeto de una investigación bioantropológica en febrero y marzo de 2018. Los resultados revelaron que al menos ocho personas habían sido enterradas en las tumbas. Los hallazgos han incrementado nuestra comprensión sobre las categorías de edad y la condición física de las personas elegidas para ser sacrificadas durante el ritual de capacocha.

Palabras clave: Inca, capacocha, Misti, sacrificios humanos

$\mathrm{T}$ he Inca Empire was the largest political entity in precolumbian South America. Beginning with a small state in the Valley of Cusco, the Incas by the early sixteenth century had conquered a territory of almost two million square kilometers. Much of this conquest was made possible through military means, but the Incas also developed alternative ways of controlling conquered lands based on economic, ideological, and indirect political methods, such as the redistribution of goods and the religious domination of those areas (Malpass and Alconini 2010:44-74). Ideological control had its foundation in religious syncretism and introduction of the imperial cult in the conquered provinces.

Dagmara M. Socha (d.socha@uw.edu.pl, corresponding author) — Center for Andean Studies, University of Warsaw, 00927, Krakowskie Przedmieście 26/28, Warsaw, Poland

Johan Reinhard — National Geographic Society, 1145 17th St. NW, Washington, DC 20036, USA (johanreinhard@ hotmail. com)

Ruddy Chávez Perea — Museo Santuarios Andinos, Universidad Católica de Santa María, 04001 Calle la Merced 110, Arequipa, Peru (ruddyperea@ hotmail.com)

Latin American Antiquity 32(1), 2021, pp. 138-153

Copyright (C) The Author(s), 2020. Published by Cambridge University Press on behalf of the Society for American Archaeology. This is an Open Access article, distributed under the terms of the Creative Commons Attribution licence (http://creativecommons.org/licenses/by/4.0/), which permits unrestricted re-use, distribution, and reproduction in any medium, provided the original work is properly cited. doi:10.1017/laq.2020.78 
The beliefs of precolumbian Andean peoples were strongly related to the landscape, ethnicity, and common ancestor cults. They were manifested as huacas, sacred places or objects worshiped by the local communities. In the highlands, powerful huacas were often identified as mountains. During warfare, the Incas would capture some of the most important idols and take them to the imperial capital of Cusco (Szemiński and Ziółkowski 2006:116-117). To help gain greater control over local communities, the Incas also determined the hierarchy of the huacas by supporting the maintenance of their priests and shrines with privileges and ritual offerings. To demonstrate these huacas' connections with the imperial cult, the Incas adapted some of the royal rituals to important local deities, providing them with a high rank and state support. One of the most important of these rituals was the capacocha, which required prestigious goods and human sacrifices.

This article presents the results of the bioarchaeological analysis of child sacrifices on Misti volcano in southern Peru (Figure 1). The Misti sacrifices constitute one of the most important examples of the capacocha ceremony found to date. The burials were discovered during an expedition led by Johan Reinhard and José Antonio Chávez in 1998 (Reinhard 2006:237256). The site was located just below the summit on the inner rim of the crater, which affected the preservation of the sacrificial offerings (Figure 2). Misti's capacocha site contained a number of human remains and fine objects made from gold, silver and spondylus shells. The analysis of the human sacrifices reveals new data about the significance of this ritual and the religious syncretism used by the Incas in the provinces.

\section{Capacocha Ritual}

Rituals requiring human sacrifices were widespread in the precolumbian Andes. Information about Inca human sacrifices, capacocha, appears in several early Spanish sources (Acosta 1962 [1590]; Betanzos 1996 [1551-1557]; Cobo 1990 [1653]; Gonzalez Holguín 2007 [1608]; Guaman Poma 1980 [1613]; Hernández Príncipe 1923 [1621]; Molina 1959 [1575]; Murúa 1946 [1590]; Polo de Ondegardo 1917 [1571];
Ramos 1976 [1621]; Ulloa Mogollón 1965 [1586]). The origin of this word is still unclear, and it is transliterated in several ways. The term capacocha (qhapaq qocha) has its origin in the Quechua language (Gonzalez Holguín 2007 [1608]:70, 77; Szemiński and Ziółkowski 2006:335). The word capac means royal, and cocha is usually translated as water or lake, primary sources of fertility. When used together, the word capacocha suggests that the Incas viewed this type of human sacrifice as being a royal offering associated with fertility (Reinhard and Ceruti 2010:6). The capacocha ritual was also often connected with the water cult (Cobo 1990 [1623]:111-112). Many sacrifices were made as a response to problems with water, such as droughts and flooding caused by the El Niño phenomenon (Reinhard and Ceruti 2005:9-10).

The term capachucha (qhapaq hucha) was used by some chroniclers instead of capacocha. Since hucha has been defined as "sin" (Gonzalez Holguín 2007 [1608]:44), some interpreted capachucha as signifying a royal obligation. The Incas believed that major disasters, ranging from the illness of an emperor to bad weather affecting crops, were brought about by events that were caused by angered deities. Only a major offering could reestablish stability in the empire (Reinhard and Ceruti 2010:8), thereby making the Inca emperor a protector with the power of negotiating with huacas.

The capacocha was related to two kinds of events (Cobo 1990 [1623]:111-112; Hernández Príncipe 1923 [1621]:34). First, it was connected to the life of the emperor and other important events affecting the empire as a whole. Children were described as being sacrificed when the emperor took the throne, when an heir was born, when the Inca emperor suffered a severe illness or died, or when major warfare occurred. Second, it was connected to significant events occurring in the province, such as cyclical activities connected to the local cult or as a response to current events; for example, a local earthquake, climate disasters (droughts, hailstorms, etc.), volcanic eruptions, and epidemics that required the Inca emperor's direct intervention. The ruler was responsible for protecting his subjects, and through these capacocha rituals Incas not only legitimized their rule but also put themselves 


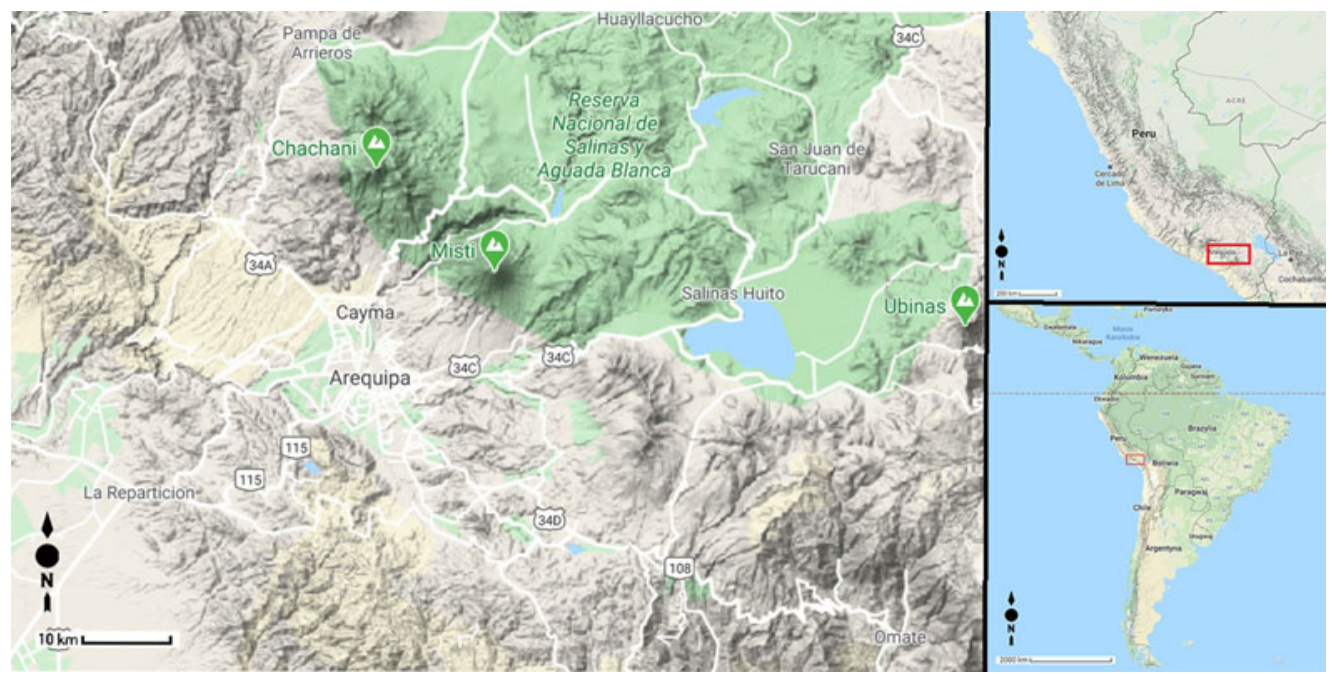

Figure 1. Map of the Misti area (Google Maps). (Color online)

and the imperial cult in a higher position than other local huacas (Cobo 1990 [1623]:111; Molina 1959 [1575]:96). Access to participation in capacocha sacrifices also determined the importance of the huaca in the imperial pantheon. Given the connection between the sacred landscape and local groups, Incas were able to determine the hierarchy of local caciques (leaders) by creating requirements for them to participate in religious activities and rituals provided by the state.
According to the chronicles, capacochas were not only connected to the ritual sphere of life but could also have involved local economic concerns. The most famous example is that of Tanta Carhua, where the initiative to perform a capacocha ritual came not from the Incas but from their subjects (Hernández Príncipe 1923 [1621]:52). Parents reportedly volunteered their daughter as a sacrifice on the promise of the construction of a new irrigation channel. Thus, sacrificing a daughter enabled them not only to increase their social status but

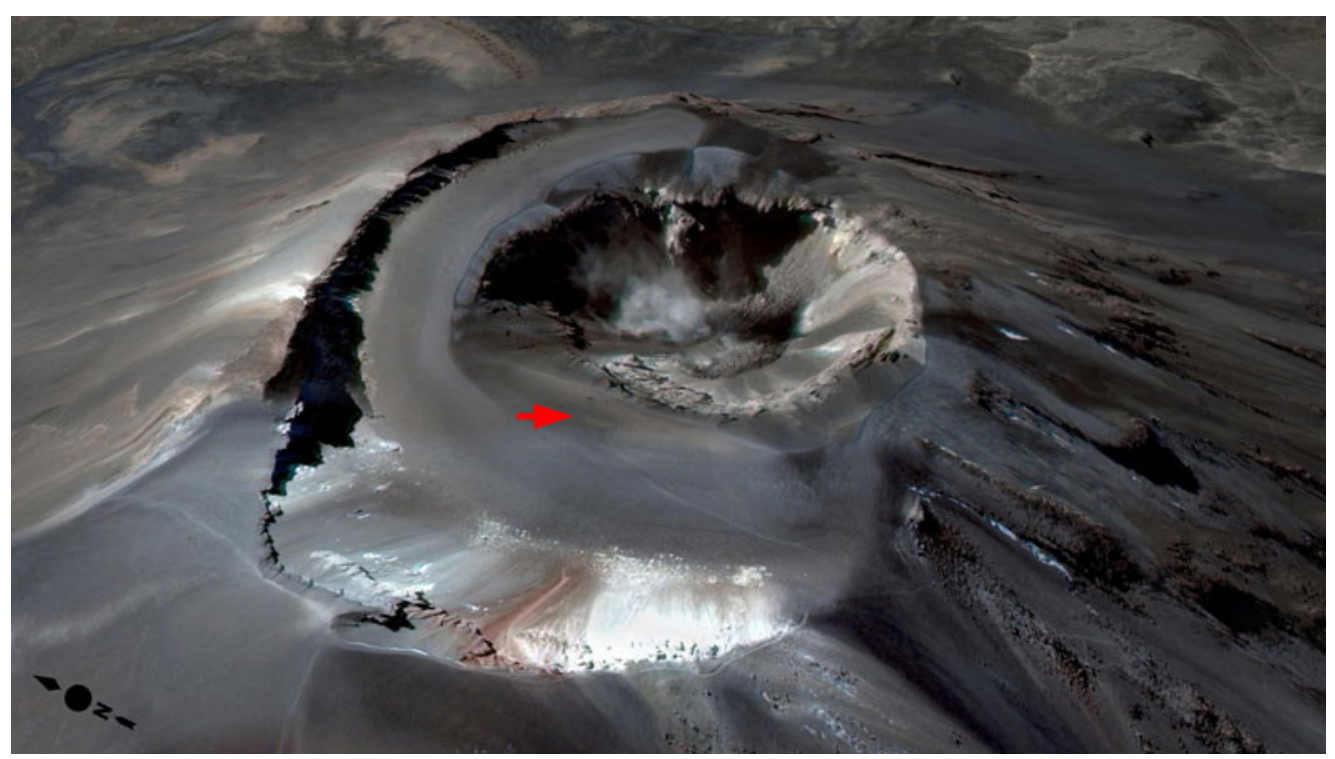

Figure 2. View of the Misti volcano and burial place (arrow; Google Earth). (Color online) 
also to obtain Inca support for construction of a new irrigation system.

The capacocha also involved luxury goods that could have been provided only by the state (Bray et al. 2004). By controlling trade and mining, Incas put themselves in a position of being the unique redistributors of long-distance trade goods, metal objects, and luxury ceramic vessels.

Some chroniclers wrote that children between the ages of 4 and 10 years old were sacrificed (Figure 3; Murúa 1946 [1590]:342; Polo de Ondegardo 1917 [1571]:37). Some also mentioned infants, but no archaeological finds have been made to confirm children younger than four years of age having been sacrificed (Cobo 1990 [1623]:112; Guaman Poma 1980 [1613]:245). The age of individuals discovered in capacocha contexts generally varies from about 4 to 20 years old (Checura 1977:127; Reinhard and Ceruti 2005:17-18).

According to the chronicles, great attention was paid to the selection of human sacrifices; having one's child chosen was seen as a great honor for the family. Often children from high-status families were selected. Those to be sacrificed were to be beautiful with no blemishes, and the females were still to be virgins (Ramos 1976 [1621]:56). For this reason, the chronicles report that acllas- females designated for royal service who were required to remain virgins - could be selected for capacocha sacrifices (Acosta 1962 [1590]:24; Hernández Príncipe 1923 [1621]:60-61).

Some sources mention a sacred marriage between the boys and girls chosen to be sacrificed (Betanzos 1996 [1551-1557]:77). However, this information is not confirmed in archaeological records: generally the capacochas have involved a single burial, the burial of two females, or mixed burials of three or more individuals (Reinhard and Ceruti 2010). The individuals are also separated in different burials. Misti is the only known example of a capacocha on the summit of a mountain where individuals share collective tombs (Reinhard 2006).

The system of the selection and redistribution of the children is not well established. According to some chronicles, they could be chosen from high-status ayllus (kinship groups) and acllahuasis (buildings for housing chosen women; Cobo 1990 [1623]:112; Ramos 1976
[1621]:56). However, some children were selected from local communities. In the chronicle of Hernández Principe (1923 [1621]:41), many of the children sacrificed as capacochas came from distant provinces, such as Ecuador, and had been voluntarily offered by their parents. After these children were transferred to Cusco, they had to take part in festivals and ceremonies and then were sent to places of sacrifice. Some of them, like Tanta Carhua, were returning to their original place of birth, whereas others were sent to distant provinces. The journey from Cusco to the place of sacrifice could take months, and it is unlikely that the youngest children could walk for such long distances (Reinhard and Ceruti 2005:13-17). Especially during the last part of the voyage, when they were ascending the mountain, they were probably carried in a litter.

There is some debate in one or two cases, but most traumas observed in the osteological material from capacochas have been identified as being perimortem and related to the method of killing the children during the final moments of the ritual (Reinhard and Ceruti 2010; Schobinger 1966, 2001). For most of the cases of capacochas it has not been possible to establish the cause of death. The best-preserved mummies from Llullaillaco do not have any trace of trauma, which leads to the conclusion that the children were suffocated or buried alive. In the case of three individuals (the Ampato maiden, the Sara Sara female, and one of the Pichu Pichu girls), there is visible evidence of trauma caused by a blow to the head. However, because they were juveniles (between 14 and 16 years of age), they could have been conscious during the ceremony and may have resisted it. The presence of vomit in a boy from Aconcagua and the Llullaillaco children could signify that they suffered great stress before their deaths (Bárcena 1989; Wilson et al. 2013); however, it could also have been due to altitude sickness or the consumption of coca leaves and alcohol (and possibly drugs) in the final stage of the pilgrimage. In the cases of El Toro and Cerro Esmeralda, visible traces of strangulation were found on the necks of victims (Checura 1977:129; Schobinger 1966), although the El Toro man was not a classical capacocha sacrifice. In any event, strangulation and 


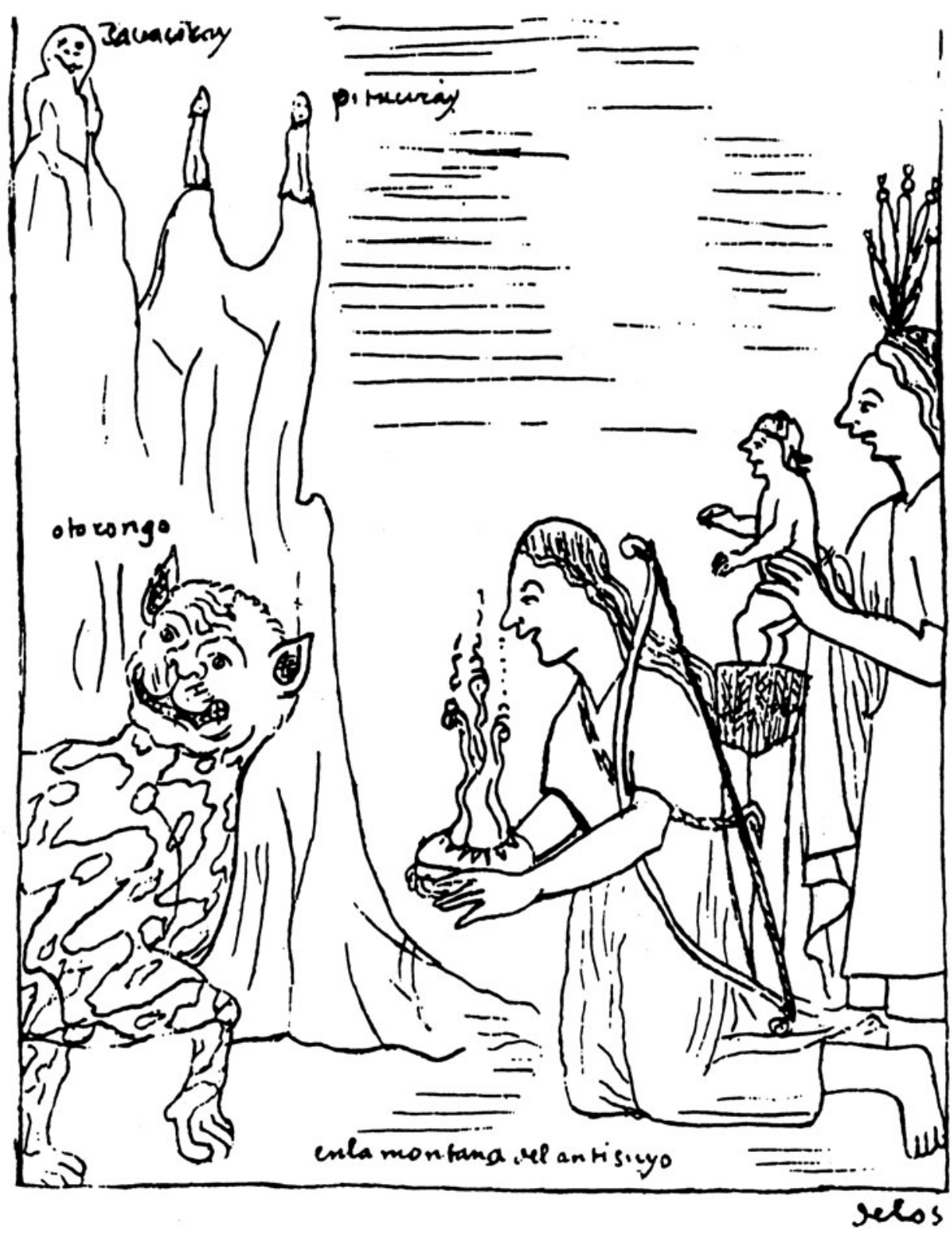

Figure 3. The offering of a child to a mountain from the chronicle of Guaman Poma (1980 [1623]:268).

suffocation do not always leave marks. According to some hypotheses, the Incas may have preferred burying alive and suffocating their victims, because doing so did not cause bleeding, and the victim could be sacrificed without an obvious wound and thus remain unblemished.

The ritual of capacocha had as its purpose not only to engage the community where the sacrifice took place but also all those along the processional path leading to it. In this way, the Incas could not only demonstrate their power but also convey the prestige of a capacocha ceremony and the distinction given to the loyal group that participated in it. It not only created the need to participate in the ritual but also became a form of indirect control through the redistribution of 
access to the prestigious ritual and the privileges provided to the conquered subjects.

\section{History of Capacocha Discoveries}

Information about the capacocha ritual has been available since the time of the Spanish conquest. However, the first discoveries of capacocha sacrifices on high mountains were made in the nineteenth and twentieth centuries (Reinhard and Ceruti 2010:9). Unfortunately, most of the capacochas were first found by grave robbers, who destroyed the burial sites, sometimes using dynamite. The first capacocha was discovered in 1896 on the summit of Chachani volcano in Peru. The burial was investigated by Wagner, a German traveler (Beorchia Nigris 1985:65-66). He found the skeleton of a woman with the remains of associated funerary offerings, including ceramic vessels and keros (ritual drinking cups). The next two, on Chañi (1905) and Chuscha (1921), were found in present-day Argentina (Reinhard and Ceruti 2010:9; Schobinger 2003). The lengthy exposure to the elements and poor storage conditions after the discovery led to decomposition of the soft tissue. The body from Chañi belonged to a five- to six-year-old individual, and it is part of the collection of the Museo Etnográfico de Buenos Aires. The mummy from Chuscha is preserved in a better state. It belongs to an eight- or nine-year-old girl and was the subject of aDNA and toxicological studies at the beginning of the twenty-first century.

The next discovery was also made by looters: a mummy of a boy of around eight years old was found on the summit of el Plomo in Chile (Sanhueza et al. 2005). The mummy and part of the funeral assemblage were donated to the Museo Nacional de Historia Natural in Santiago. The next body was found on Pichu Pichu in southern Peru in 1963 (Reinhard 2006:170-172). The tomb was located on a partially collapsed artificial platform on the summit. Soon after that, climbers found the body of a young man in Argentina, near the summit of El Toro mountain in 1964 (Schobinger 1966). The man was wearing only a loincloth, and his neck had evidence of strangulation. The nontypical age category and the lack of elaborate clothing and of a grave assemblage led to the conclusion that El Toro is probably a case of another type of event, not related to a state-sponsored capacocha ritual (Reinhard and Ceruti 2010:132). The capacochas from Cerro Esmeralda were discovered in 1976 in northern Chile during road construction (Checura 1977). The bodies belonged to two females of 9 and 18-20 years old. The first definite capacocha found in context by archaeologists was recovered on Aconcagua (Schobinger 2001). It contained the body of a seven- to eight-year-old boy, ceramic vessels, and objects made from silver and gold. The body was bound by ropes so tightly that it led to the fracturing of some of the bones and the displacement of pelvic bones. The individual suffered great stress before his death: the body was found covered by fecal matter and vomit (Bárcena 1989).

Johan Reinhard began his research of highaltitude archaeological sites in Peru, Chile, and Argentina in 1980, and he and José Antonio Chávez first excavated a capacocha sacrifice in 1989 on Pichu Pichu (Reinhard 2006:170 172). Reinhard and Miguel Zarate found the first frozen Inca female mummy on Mount Ampato in September 1995. After that, from October 1995 to 1999, Reinhard and Chávez organized several expeditions to mountains in Peru and (with codirector Constanza Ceruti) in Argentina, which led to discoveries of further human sacrifices on (or near) the summits of Ampato, Pichu Pichu, Misti, Sara Sara, Quehuar, and Llullaillaco (Reinhard 2006; Reinhard and Ceruti 2010). In total, they found human remains belonging to 20 individuals, varying in age between about 4 to 15 years old.

\section{Misti Expedition}

Misti volcano was characterized by chroniclers as an aggressive deity that demanded many sacrifices. The chronicler Martin Murúa (1946 [1590]:42) mentioned that during Inca times a major eruption of Misti took place that devastated the people living in the region. To help protect their subjects, the wife of the Inca emperor Pachacutec, Mama Ana Huarque Coya, made sacrifices in Cusco temples to appease the anger of the huaca. Pachacutec is 
reported to have personally traveled with priests to the mountain to make sacrifices. In colonial times Misti (called Putina before the arrival of the Spanish) was still shrouded in local beliefs. Colonial sources mention the pilgrimage led by a local Catholic priest to exorcise the volcano (Reinhard 2006:241).

The archaeological expedition to Misti's summit took place in 1998 (Reinhard 2006:237-256). The archaeologists did not expect to find an undisturbed sacrifice, because easy access to the summit meant that the volcano had been repeatedly climbed for many years and was widely reported to have been searched by looters. During excavations on the interior rim of the volcano crater, however, the archaeologists found one of the most impressive capacocha sacrifices ever discovered. It contained eight (and possibly nine) human skeletons and 47 figurines made from gold, copper, silver, and spondylus shell; ceramic and wooden vessels; bone and lithic artifacts; and Spondylus sp. shell (see Table 2; Supplemental Figures 1-10).

The site of the capacocha was located inside the crater about $100 \mathrm{~m}$ below the volcano's highest point $(5,822 \mathrm{~m})$. Despite the elevation, the summit of Misti is covered by snow only during half the year, and the conditions vary dramatically between night and day. The temperature inside the crater is even higher because of volcanic activity, which prevented the Inca bodies from remaining frozen. The meteorological changes strongly affected preservation of the organic material. The ground inside the crater is also acidic, which accelerated decay of the bodies and textiles (Reinhard 2006; Reinhard and Ceruti 2010:16).

The burials show evidence of having been hit by lightning strikes. Thunderbolts frequently hit capacocha sacrifices; for example, the younger girl on Llullaillaco and the mummies of a boy and girl found below Ampato's summit at 5,800 $\mathrm{m}$ (Reinhard and Ceruti 2005). The lightning strikes may have been caused not only by the location of the burials high on mountains but also by the presence of metal objects. Some scholars have suggested that the locations of the burials were chose deliberately, because lightning strikes were desired by the Incas
(Reinhard and Ceruti 2010:132). Illapa (the weather deity and controller of lightning and thunder) was one of the most important deities after Inti (the Sun), Quilla (the Moon), and Wira Quchan, the creator deity in Inca mythology (Cobo 1990 [1623]):48-50). Some scholars note that Illapa was the divine counterpart of the Inca emperor (Szemiński and Ziółkowski 2006:150-152). The connection between the representation of state religion by Illapa and the capacochas for the local huacas could be a result of religious syncretism implemented by the Incas as a deliberate strategy in the conquered territories. In this way the mountain deities would likely have been perceived by the Incas as subordinate to the Inca state deity, Illapa (Reinhard and Ceruti 2010:132).

The capacochas from Misti were extraordinary not only because of the abundance of artifacts but also the atypical architecture of the burials (Reinhard and Ceruti 2010). In other cases of capacochas on mountain summits, the children were usually buried inside artificial platforms made from stones, placed close to the summit or on an exposed surface. In Misti, archaeologists found one artificial platform, which was probably used for rituals, along with two collective tombs C2 and C3 (Figure 4; Reinhard 2006:237-256). The sex of the individuals buried inside the tombs was hypothesized based on the presence of male or female figurines. The burials were each marked by a circle of stones and to a depth of about $2 \mathrm{~m}$. Because of the difficult conditions inside the crater and the state of preservation of the human remains, the team decided not to excavate the bodies in situ but to extract them within frozen blocks of soil (Figure 5). Based on the parts of the remains that were visible during excavation, it was thought that each tomb contained three individuals, one above and two on the bottom. The approximate ages at death in each burial were estimated to be one adult, one child, and one infant. The ground was frozen by the team pouring water on burials during the night. The next morning the bodies were excavated with the frozen soil and later transported to the Museo Santuarios Andinos at Universidad Católica de Santa María in Arequipa. The bodies were stored in a refrigeration chamber until 2018, when they 


\section{Drawing 1}
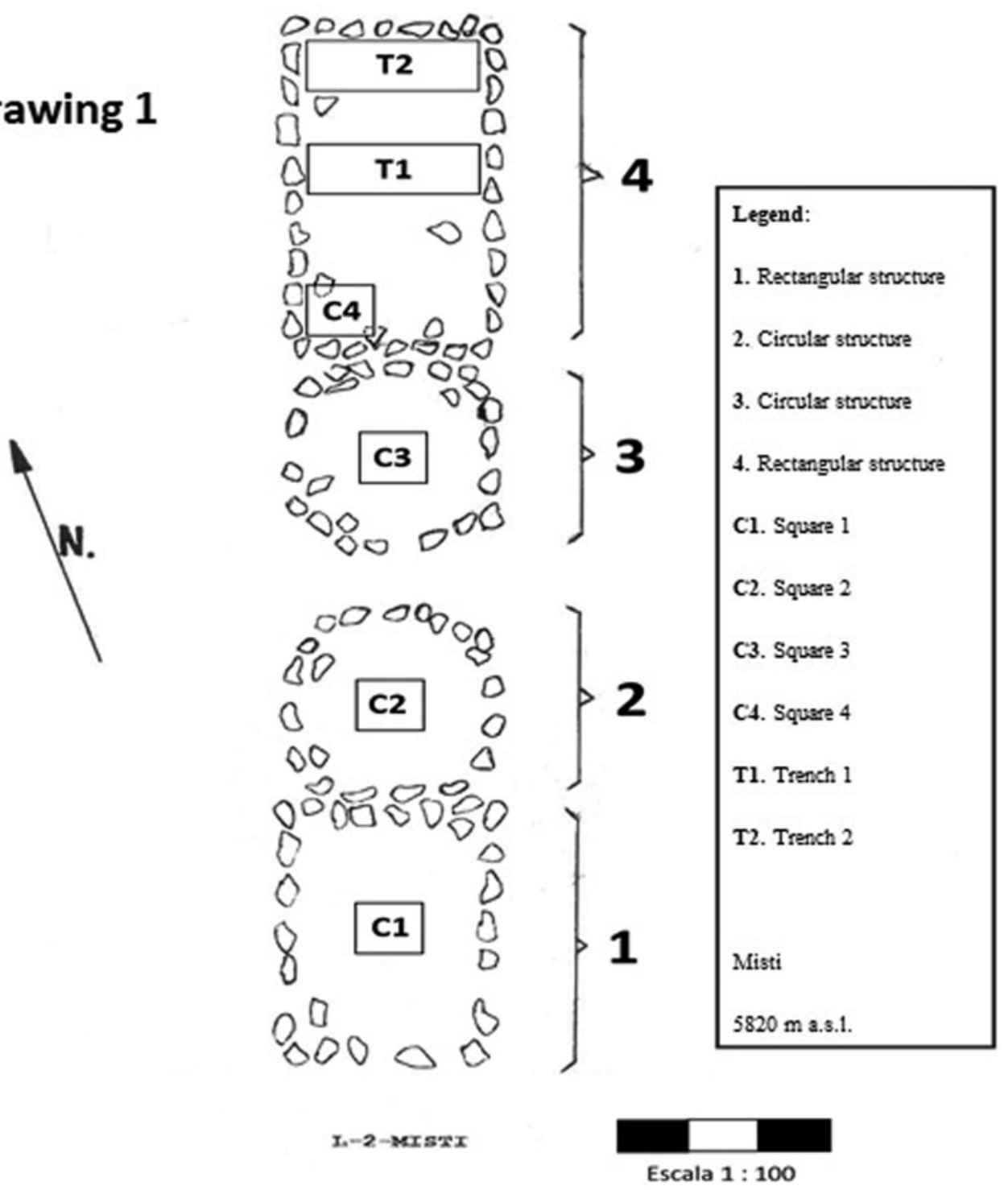

Figure 4. Plan of the structure of the tombs and the areas excavated.

were subjected to a bioarchaeological study for the first time.

\section{Material and Methods}

Because of the state of preservation, the blocks of soil first had to be unfrozen and then the skeletal remains cleaned of soil. The process of thawing was done on special sieves to avoid the accumulation of water. The harsh environmental conditions inside the Misti crater led to the full skeletonization of the bodies. Due to changes in temperature and the lightning strikes, the bones were highly fragmented and partially burned. Based on the color of the bones, it was possible to determine that lightning did not hit the bodies directly but was close enough to significantly raise the temperature of the soil. In some cases of capacocha burials where lightning struck the bodies directly, the bones were white due to the effect of high temperature, even if the rest of the bodies were still completely 


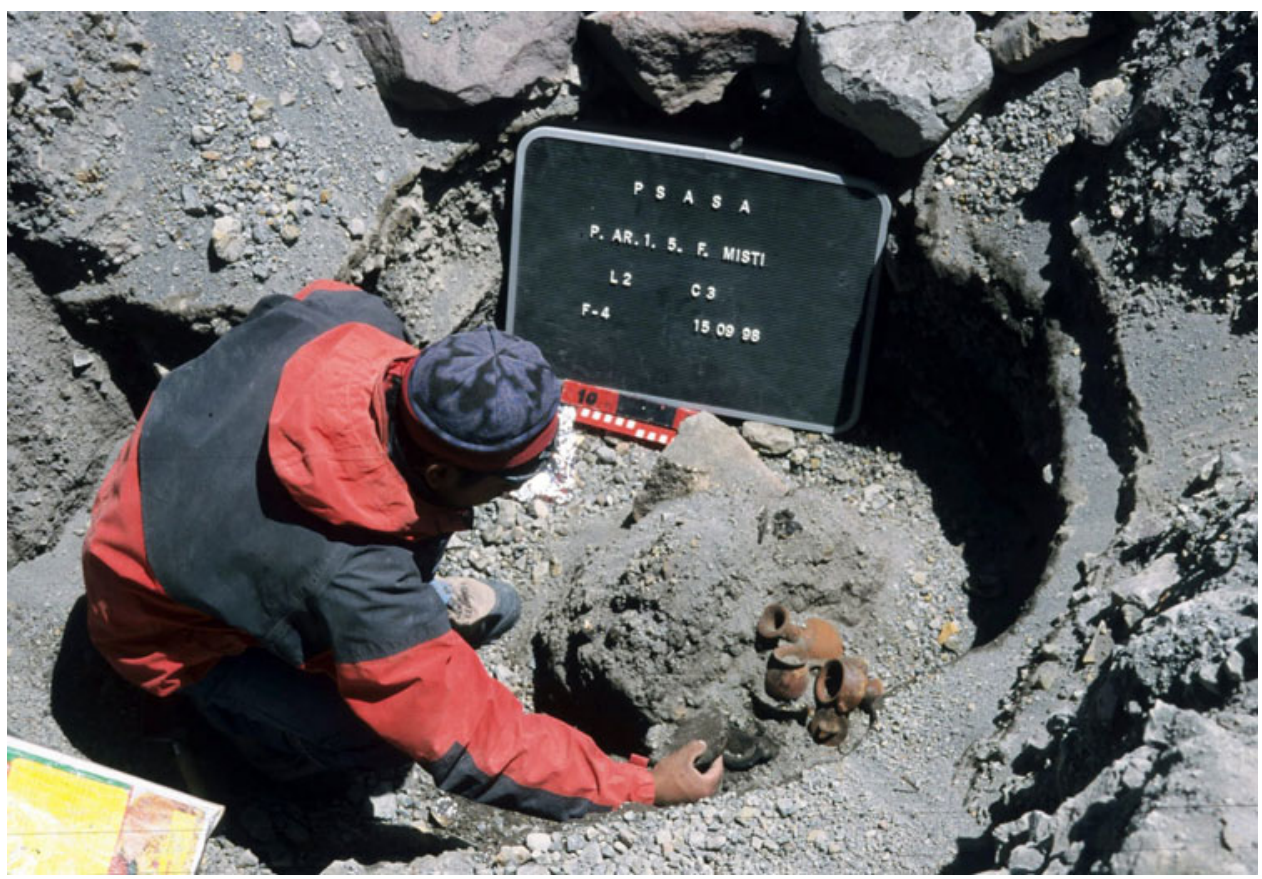

Figure 5. Excavation of the site with probable female burials (photo by Johan Reinhard). (Color online)

mummified. In other cases, such as with the younger girl from Llullaillaco, the lightning burned only the external part of the mummy's face and textiles because of the stable climate conditions on the summit (Reinhard and Ceruti 2010).

The bioarchaeological analysis established the age at the time of death, activity patterns, and the presence of pathologies, traumas, and disease. For the youngest children, the sex was impossible to establish based only on the bones (Schaefer et al. 2009); however, the figurines and items of clothing, such as tupus (female shawl pins), suggested the sex of the sacrificial victims.

The age at the time of death was established based on teeth eruption, size of the bones, and state of fusion of the epiphysis of the long bones (Gaither 2004; Schaefer et al. 2009; Ubelaker 1979). The patterns of activity are possible to trace because of the development of muscular unions and, in some cases, changes in the geometry of the bones and lesions of the joint surfaces.

\section{Results}

The investigation of the capacochas from Misti revealed not only an unexpected number of individuals but also suggested revisions to our understanding of the age categories and health conditions of the sacrificed individuals. Based on other capacocha findings, the victims were often young women in their teenage years and children between 4 and 10 years old (Reinhard and Ceruti 2010:104-106). The males were buried alone or with two females, one of whom was of a similar age. After cleaning the bones from Misti of soil, it was discovered that a total of eight or nine individuals were buried in two tombs (Table 1).

\section{The C2 "Male" Tomb}

In the $\mathrm{C} 2$ tomb, the sex of the individuals was hypothesized based on objects buried with them, which consisted of several male and llama male figurines (Table 2; Supplemental Figures 1, 2, 5-7). Fragments of gold, silver, and copper foil that could be the remnants of jewelry were also present. During the investigation of osteological material, epiphyses and diaphysis of animal bones were found; these bones probably belonged to camelids. The distal part of the best-preserved epiphysis of the femur was still not fused. It suggests that, like the individual 
Table 1. List of Individuals from Misti.

\begin{tabular}{|c|c|c|c|c|}
\hline $\begin{array}{l}\text { Number Assigned } \\
\text { to Individual }\end{array}$ & $\begin{array}{l}\text { Sex based on } \\
\text { Grave Goods }\end{array}$ & Age & Pathology & Associated Objects \\
\hline Misti 1 & Male & $13 \pm 3$ years & Curved legs & \\
\hline Misti 2 & Male & $6 \pm 2$ years & Dental wear & \\
\hline Misti 3a & Male & $6 \pm 2$ years & Dental wear & \\
\hline Misti 3b & Male & $6 \pm 2$ years & Dental wear & \\
\hline Misti SN 1 & Male & $6 \pm 2$ years & & \\
\hline Misti SN 2 & Male & $6 \pm 2$ years & & \\
\hline Misti 4 & Female & $10 \pm 2$ years & & Collar \\
\hline Misti 5 & Female & $6 \pm 2$ years & & Two tupus \\
\hline Misti 6 & Female & $6 \pm 2$ years & & $\begin{array}{l}\text { One tupu and unku* with } \\
\text { silver and gold discs }\end{array}$ \\
\hline
\end{tabular}

* Since only the metal elements were preserved, we don't know the form of the textile for sure, but based on others (like one from Pichu Pichu), it is probably an unku.

Table 2. List of Artifacts from C2 and C3 Tombs.

\begin{tabular}{|c|c|c|c|c|c|}
\hline \multicolumn{3}{|c|}{ C2 "Male" Tomb } & \multicolumn{3}{|c|}{ C3 "Female" Tomb } \\
\hline Type of Object & Material & Number & Type of Object & Material & Number \\
\hline \multirow[t]{4}{*}{ Human male figure } & Spondylus sp. & 3 & Human female figure & Spondylus sp. & 5 \\
\hline & Copper & 1 & & Copper & 1 \\
\hline & Silver & 1 & & Silver & 2 \\
\hline & Gold and copper & 2 & & Gold and copper & 1 \\
\hline \multirow[t]{6}{*}{ Llama figure } & Spondylus sp. & 18 & Тири & Silver & 9 \\
\hline & & & Collar & Silver and copper & 1 \\
\hline & & & Unku & $\begin{array}{l}\text { Camelid fiber textile with } \\
\text { silver and gold discs }\end{array}$ & 1 \\
\hline & Copper & 1 & Plate & Wood & 2 \\
\hline & Silver & 10 & Spoon & & 1 \\
\hline & Gold and copper & 2 & Рисси & Ceramic vessels & 12 \\
\hline Shell & Spondylus sp. & 7 & Aisana & Ceramic vessels & 3 \\
\hline \multirow[t]{3}{*}{ Metal piece or foil } & Gold & 2 & Aryballos & Ceramic vessels & 4 \\
\hline & Silver & 1 & Jarra & Ceramic vessels & 3 \\
\hline & Gold with copper & 3 & Olla & Ceramic vessel & 1 \\
\hline Tumi (knife) & Copper & 1 & & & \\
\hline Carved artifact & Bone fragments & 2 & & & \\
\hline Round stone & Lithics & 3 & & & \\
\hline Рисси & Ceramic vessels & 5 & & & \\
\hline Jarra & Ceramic vessels & 2 & & & \\
\hline Aisana & Ceramic vessel & 1 & & & \\
\hline
\end{tabular}

with whom the bones were buried, the animal was also young. The skull bones or teeth of the animal were not found. It is most likely that only the lower limb of the animal was buried with the children. Burying the children with young llamas or alpacas could have been part of the ceremony based on rules of similarity.

After cleaning the soil from the blocks, it was discovered that the $\mathrm{C} 2$ tomb contained five or six bodies. The oldest individual (Misti 1) was around 13 years old; the rest (Misti 2, 3a, 3b, $\mathrm{SN} 1$, and SN2) were around six years of age. All the bones were fragmented and partially burned by lightning strikes. The four individuals (Misti 1, 2, 3a, and 3b) had preserved jaws, skull bones, and long bones in a state sufficient to allow determination of their age and some activity patterns. Unfortunately, the bodies that were probably placed on the upper part of the tomb were completely destroyed (Misti SN1 and 
SN2). Only the teeth were preserved in a state that allowed determination of the age as six years old. Because the bones were packed in two separate blocks of soil, it was impossible to determine if they belonged to one or two individuals. None of the teeth were duplicated, and the state of formation and size were very similar, but aDNA tests would need to be conducted to establish if they were from one individual.

The anatomical order was altered in the other four cases (Misti 1, 2, 3a, and 3b). In the places where it was still possible to observe their anatomical position, the children were buried in a sitting position with knees close to their chests. Three younger individuals (six years old) had traces of advanced tooth wear of the posterior part of the crown of the first molars and milk teeth $\mathrm{E}$ (Figure 6). This characteristic was more visible in the upper teeth, but it was possible to observe it in the lower teeth as well. This type of wear is probably related to some chewing pattern or the use of teeth during some activity. It could also be related to frequently putting hard objects in the mouth, such as a pipe. Two individuals from grave $\mathrm{C} 2$ (Misti 2 and 3a) had traces of caries, suggesting a diet rich in sugar.

The femurs of the individual Misti 1 have curved diaphysis (Figure 7). This condition probably hindered walking. Unfortunately, there are no preserved patella and tibias to see how it affected the lower bones. The genesis of this disease is difficult to determine. One of the possibilities is genu valgum, which is caused by malnutrition or rickets. In addition to an inadequate diet, genu valgum can also be caused by the concentration of some chemical elements that stunt normal growth. These elements include fluorides that may appear in shallow groundwater (Khandare et al. 2005). The poisoning of water could have occurred in ancient Peru because the geological structure of a mountain is rich in substances that are toxic to humans (Arriaza et al. 2010). Rickets is caused by an insufficient level of vitamin $\mathrm{D}$ in the body. It often occurred in northern Europe (Ogden 2006), but because the human organism produces vitamin D when exposed to sunlight, it is unlikely to have occurred in Peru.

Cases of trauma or postdeposition processes do not produce symmetrical changes (Ogden 2006). Therefore, because the lesion is symmetric, it

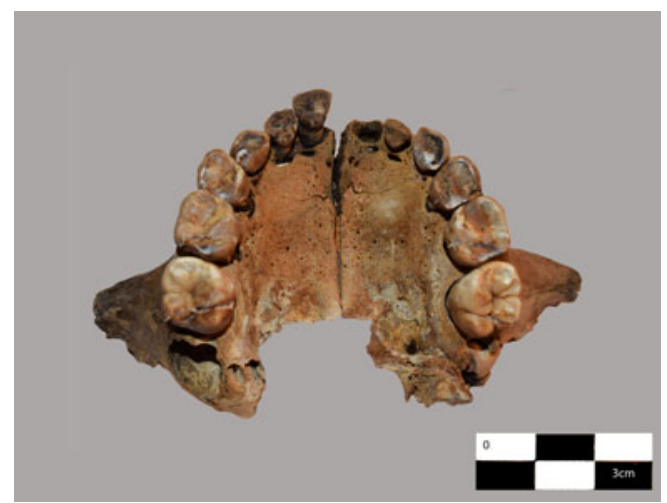

Figure 6. The wear of posterior parts of the crowns of the first molars and milk teeth $E$ (photo by Dagmara Socha). (Color online)

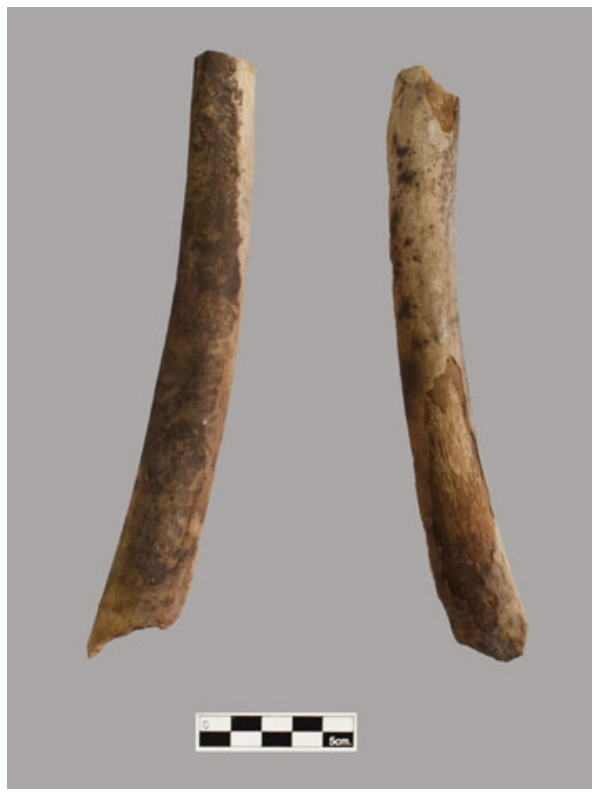

Figure 7. The diaphysis of the femur of the Misti 1 individual (photo by Dagmara Socha). (Color online)

was most likely caused by a growth or genetic disorder. A similar lesion was found in the Sunghiri child burial (Sunghir 3 burial; Formicola and Buzhilova 2004:191-195) and also at the Inca site of Maucallacta (Socha 2011:69-71). At Maucallacta the investigation of Chullpa 1 revealed that nearly $33 \%$ of individuals had the same femur pathology (the minimum number of individuals buried at chullpa was estimated at 167).

The young age of the individual excludes the possibility of the lesions being caused by hard 
work. When bones are under high pressure for a long time they change their geometry, related to a greater attachment of the muscles and, sometimes, traumas (Waldron 2008). In the case of Misti 1, there is no trace of high muscular activity. The defect's appearance in a juvenile individual confirms the hypothesis that it is the result of inheritance or factors that inhibit growth. Changes of this type are mostly associated with fetal or early life and childbirth. Improper delivery, especially during breech labor, can lead to malformation (Ogden 2006). However, for the most part, they are accidental, and such changes do not become permanent. It is possible that the lesion was caused by a hereditary disease. However, changes in the femurs caused by genetic diseases are more often associated with other deformities that are found mainly in the craniofacial region (scaphocephaly, macrocephaly, micrognathia) and the feet, such as clubfoot (talipes equinovarus; Hall and Spranger 1980). Unfortunately, the bones of the foot and the cranium were in poor condition.

The most probable hypothesis is the alteration of cartilage growth. These types of changes can begin during fetal life. It can be caused by abnormal growth of the cartilage in the centers of ossification (Hitti 1994) or be related to genetic factors, poor diet, and the health condition of the mother. In particular, maternal diabetes, resulting in an abnormally high concentration of glucose, affects the development of fetal cartilage (Leonard et al. 1989). The deformation of the extremities can also be influenced by an inadequate diet during infancy. If, at the time of learning how to walk, the child did not have sufficient nutrients, it could lead to the creation and consolidation of the resulting deformation. A diet based mainly on maize could have such an effect. One of the first meals that children received when they were weaned onto solid foods in precolumbian Peru was corn paste. It is caloric but also poor in protein and iron and thus could eventually lead to anemia and poor bone formation. In the case of a rapid transition from mother's milk to solid food, the weaning stress combined with the lack of bone-building substances could cause consolidation of this type of pathology. The proportion of meat in
Andean diets was small (Costin and Earl 1989:696). In mountainous areas, frequent meat consumption was reserved mainly for those in the highest social strata. Within the precolumbian Andean area, there were no dairy products that could provide proteins. It is possible, therefore, that the deficiencies that led to the malformation of the bones were the result of the predominance of maize in an unbalanced diet lacking meat and dairy products.

\section{The C3 "Female" Tomb}

Three bodies were discovered in the $\mathrm{C} 3$ tomb (Misti 4, 5, and 6): one individual was around 10 years old (Misti 4), and two were around six years of age (Misti 5 and 6). As in the $\mathrm{C} 2$ burial, all the bones were fractured and partially burned. In all cases, the anatomical order was altered. The individuals were also buried in a sitting position. Most of the bones were fragmented, which prevented the possibility of any measurements. In contrast to the $\mathrm{C} 2$ burial, the individuals buried in $\mathrm{C} 3$ did not have any specific dental patterns or bone pathologies.

Collars, female figures, and tupus made of gold, copper, silver and spondylus, as well as wooden and ceramic vessels, were found with the burials (Table 2; Supplemental Figures 8-10). Each individual had jewelry made of metal (Table 1). Moreover, the body of Misti 6 was buried with a coat or tunic decorated with large and small sequins and a silver tupu. Only small fragments of the rope that linked the sequins had preserved textiles. On the upper part of the coat, there was a row of silver discs with a diameter of $50 \mathrm{~mm}$. The lower part was covered by more than 600 gold and silver sequins of 10 $\mathrm{mm}$ in diameter. They were very thin and in poor condition. The pattern of the smaller ones made it appear that one gold row alternated with two rows of silver. The gold sequins had a copper intrusion. The mixing of gold with copper was done to achieve the golden-red color that, in the mythology of Incas, was related to the Sun (Lechtman 2007).

\section{Discussion}

The capacocha ceremony on Misti is the only one found to date inside the crater of a volcano 
(Reinhard 2006). It also had the largest number of goods and children sacrificed of any such known ceremony. It is the first discovered capacocha to have more than three bodies sacrificed in the same site (Reinhard and Ceruti 2010). It is also the only mountain capacocha occurring in collective graves. In some cases, such as Ampato, the Incas could return a number of times to the summit. The victims of Ampato were sacrificed during at least two independent ceremonies (Reinhard 2006). Three were buried on an artificial platform at an altitude of 5,850 $\mathrm{m}$ and one on the summit at $6,312 \mathrm{~m}$. In the case of Misti, the children were buried in two similar tombs. Because of the lack of clear stratigraphy and the short time span of Inca occupation, it is impossible to determine whether the tombs were constructed at the same or on different occasions.

In other capacochas, females played an important role (Reinhard and Ceruti 2010), with a young girl (around 5-8 years old) and a juvenile female (12-15 years old). The male sacrificed during the capacocha rituals were usually no older than eight years. The El Toro male would be an exception, but there are reasons to believe that he may not have been a true capacocha sacrifice (Reinhard and Ceruti 2010). According to the chroniclers, Incas selected the most beautiful children who did not have any physical defects (Betanzos 1996 [1551-1557]:6; Hernández Príncipe 1923 [1621]:60; Ramos 1976 [1621]:56). They were reported to have been buried alive or killed by strangulation or blows to the head. Female children, according to this ideology, were supposed to be virgins (Cobo 1990 [1623]:112). The lack of older boys could be explained by the absence of a tradition that protected them from losing their virginity (Reinhard and Ceruti 2010:106). Female virginity was assured because of the acllawasi; there was no similar arrangement for males.

No bioarchaeological evidence confirms the sex of the Misti children. However, the sex of the figurines that accompanied them had a very strong association with the individuals of all known cases (Reinhard and Ceruti 2005). Sometimes they reproduce the features of individuals' clothes such as headdresses (Reinhard and Ceruti 2010:195). The tири pins were also a typical female attribute. The other clothing elements such as the unku (male tunic) are questionable. The Misti 6 individual was buried in clothes decorated with gold and silver discs. A similarly decorated unku was found on the summit of Pichu Pichu. Nevertheless, at Pichu Pichu, the unku was buried as a separate sacrifice close to a female figurine (Reinhard 2006:178-179).

The discovery of Misti enhances our understanding of the capacocha ceremony. The "sacred marriage" during a capacocha ritual that is described by chroniclers has not been confirmed in the archaeological record. Some chroniclers such as Betanzos (1996 [1551-1557]:77) mentioned that the children were selected as a couple and sacrificed together. However, until now, no capacocha sacrifices that contain the same number of individuals of different sexes have been discovered. In the case of Misti, this disproportion is even more pronounced: there are probably five or six males and only three females. In addition, there is no juvenile female present, which is often the case when female victims are found in capacocha burials. Normally, the first menstruation occurred at around 12-14 years of age. The age of the older girl (Misti 4) was estimated at 10 years old, which is significant, meaning that she was more likely treated as a child. Based on the grave good sex hypothesis, the boys are in the majority, and the oldest is around 13 years old-in some cultures the age of achieving adolescence.

The bioarchaeological analysis disproves the initial theory that some of the sacrifices were infants (Reinhard and Ceruti 2005:6). The first three years of life were difficult for children in precolumbian times; in ancient societies, a high percentage of children died before reaching this age. The lack of sacrifices in this age category suggests that the Incas chose older children not only based on their beauty and origins but also because of their higher possibility of surviving the journey to the sacrifice site and remaining in good health. Most of the children (six or seven) were close to the same age. It can be hypothesized that age could have played an important role in the selection of a particular capacocha.

The analysis thus confirms the description in the chronicles about the age of the children. 
The presence of two older individuals (Misti 1 and 4) could be because locals were able to add their own children as sacrifices or that juveniles played an important religious role in the capacocha ceremony.

The deformation of the bones of the femur of the Misti 1 individual could be related to his role in the belief system. The lesion must have occurred in early childhood (about one year old when the child was learning to walk) or was congenital (Hitti 1994; Leonard et al. 1989). According to some chronicles, people hit by lightning or who had some type of genetic abnormalities such as curved legs or cleft lip were chosen to be the priests of the god Illapa (Arriaga 1968 [1621]:214-215). Several of the individuals buried as part of the capacochas had been struck by lightning after death; by situating them on high places, the Incas would have been aware that they were susceptible to lightning strikes, suggesting a special connection between Illapa and the ritual. The sacrifice of the 13-year-old individual with the curved legs could also have been related to Illapa's cult. If the child was treated as a sacred person because of his illness, this could explain his older age.

In the cases of younger, probably male, individuals, (Misti 2, 3a, and 3b), uncommon patterns of tooth wear were visible. The first molar and milk teeth $\mathrm{E}$ had worn on the posterior surface of the crown. In some cases, the space between the teeth was also disturbed. It could be related to special eating habits or, more likely, to putting something in the mouth that led to a specific wear pattern. This is the first time this type of dental wear was found in a capacocha victim; however, some studies mentioned that children of other capacocha sacrifices had a high level of dental wear (Previgliano et al. 2003:1474). The bones from Misti offer the opportunity to observe the surfaces of the teeth directly. In previous studies, because of the preservation of the soft tissues, it was difficult to open the mouths to verify the wear patterns of the teeth. The lesion could be evidence of gagging or of the individuals being given some hard object to hold in their mouths. The lack of this type of wear on individuals' teeth from the C3 tomb could also suggest they participated in different rituals.
In the time of the Incas and the colonial era, Misti was known as a deity dangerous to the people (Murúa 1946 [1590]:48). The volcano had also experienced a major eruption during the time of the Incas. Such a significant event would have required the Incas to conduct the most elaborate sacrifices, ones so important that they reportedly included the personal participation of the Inca emperor. The chroniclers report that the offerings were made primarily to placate Misti, but in Inca cosmology the volcano was likely considered as being under the control of a state deity, presumably Illapa, the Inca's weather god (Reinhard and Ceruti 2010:132). The capacochas and other state offerings on Misti demonstrate a religious syncretism and the establishment of a local hierarchy of huacas. This led to one of the most dramatic known examples of an Inca capacocha ceremony from the Andes.

Acknowledgments. Dagmara Socha acknowledges the Universidad Católica de Santa María in Arequipa for financial support of this project and the director and staff of Museo Santuarios Andinos for help and support during the research. Johan Reinhard would like to thank José Antonio Chávez, codirector of the 1998 Misti expedition, and the National Geographic Society for a grant supporting the expedition.

Data Availability Statement. All data and material used in this article are available in the Museo Santuarios Andinos of Universidad Católica de Santa María in Arequipa.

Supplemental Material. For supplemental material accompanying this article, visit https://doi.org/10.1017/laq.2020.78

Supplemental Figure 1. Silver llama figurine from the C2 tomb.

Supplemental Figure 2. Llama figurine made of Spondylus sp. shell from the $\mathrm{C} 2$ tomb.

Supplemental Figure 3. Spondylus sp. shell from the C2 tomb.

Supplemental Figure 4. Gold foil from the C2 tomb.

Supplemental Figure 5. Llama figurine made from gold and copper from the $\mathrm{C} 2$ tomb.

Supplemental Figure 6. Silver male figurine from the C2 tomb.

Supplemental Figure 7. Copper male figurine from the C2 tomb.

Supplemental Figure 8. Silver female statue with tupu from the $\mathrm{C} 3$ tomb.

Supplemental Figure 9. Silver tupus from the C3 tomb.

Supplemental Figure 10. Aryballos from the C3 tomb.

\section{References Cited}

Acosta, José de

1962 [1590] Historia natural y moral de las Indias. 2nd 
ed. Fondo de Cultura Económica, Biblioteca Virtual Miguel de Cervantes, Mexico City.

Arriaga, Pablo José de

1968 [1621] La extirpación de la idolatría en el Pirú (1621). Biblioteca de Autores Españoles, Madrid.

Arriaza, Bernardo, Dula Amarasiriwardena, Lorena Cornejo, Vivien Standen, Sam Byrne, Luke Bartkus, and Basel Bandak

2010 Exploring Chronic Arsenic Poisoning in PreColumbian Chilean Mummies. Journal of Archaeological Science 37:1274-1278.

Bárcena, Roberto

1989 Pigmentos en el ritual funerario de la momia del cerro Aconcagua. Xama 2:61-116.

Beorchia Nigris, Antonio

1985 El enigma de los santuarios indígenas de alta montaña. Revista del CIAAM Vol. 5. Centro de Investigaciones Arqueológicas de Alta Montaña, San Juan, Argentina.

Betanzos, Juan

1996 [1551-1557] Narratives of the Incas. University of Texas Press, Austin.

Bray, Tamara L., Leah D. Minc, Constanza Ceruti, Jose Antonio Chávez, Ruddy Perea, and Johan Reinhard

2004 A Compositional Analysis of Pottery Vessels Associated with the Inca Ritual of Capacocha. Journal of Anthropological Archaeology 24:82-100.

Checura, Jorge

1977 Funebria incaica en el cerro Esmeralda (Iquique, I región). Estudios Atacameños 5:127-144.

Cobo, Bernabé

1990 [1623] Inca Religion and Customs. Translated and edited by Ronald Hamilton. University of Texas Press, Austin.

Costin, Cathy, and Timothy Earle

1989 Status Distinction and Legitimation of Power as Reflected in Changing Patterns of Consumption in Late Prehispanic Peru. American Antiquity 54:691-714.

Formicola, Vincenzo, and Alexandra P. Buzhilova

2004 Double Child Burial from Sunghir (Russia): Pathology and Inferences for Upper Paleolithic Funerary Practices. American Journal of Physical Anthropology 124:189-198.

Gaither, Catherine

2004 Growth and Development Studies of Coastal Prehistoric Peruvian Populations. PhD dissertation, Department of Anthropology, Tulane University, New Orleans, Louisiana. Proquest (3170323).

Gonzalez Holguín, Diego

2007 [1608] Vocabvlario de la lengva general de todo el Perv llamada lengua Qquichua, o del Inca. http://www. letras.ufmg.br/padrao_cms/documentos/profs/romulo/ VocabvlarioQqichuaDeHolguin1607.pdf, accessed November 6, 2020

Guaman Poma de Ayala, Felipe

1980 [1613] El primer nueva crónica y buen gobierno. Siglo Veintiuno, Mexico City.

Hall, Bryan, and Jiirgen Spranger

1980 Congenital Bowing of the Long Bones. European Journal of Paediatrics 133:131-138.

Hernández Príncipe, Rodrigo

1923 [1621] Mitología andina. Revista Inca 1(1):25-78.

Hitti, Ibrahim

1994 Bilateral Femoral Hypoplasia and Maternal Diabetes Mellitus: Case Reports and Review of the Literature. Pediatric Pathology 14:567-574.
Khandare, Arjun, Rao Harikumar, and Bhatt Sivakumar

2005 Severe Bone Deformities in Young Children from Vitamin D Deficiency and Fluorosis in Bihar-India. Calcified Tissue International 76:412-418.

Lechtman, Heather

2007 The Inka, and Andean Metallurgical Tradition. In Variations in the Expression of Inka Power: A Symposium at Dumbarton Oaks 18 and 19 October 1997, edited by Richard L. Burger, Craig Morris, and Ramiro Matos Mendieta, pp. 313-355. Dumbarton Oaks, Washington, DC.

Leonard, Claire, Michael Bergman, Dorothy Frenz, Linda Macreery, and Stuart Newman

1989 Abnormal Ambient Glucose Levels Inhibit Proteoglycan Core Protein Gene Expression and Reduce Proteoglycan Accumulation during Chondrogenesis: Possible Mechanism for Teratogenic Effects of Maternal Diabetes. Proceedings of the National Academy of Sciences of the United States of America 86:10113-10117.

Malpass, Michael A., and Sonia Alconini

2010 Distant Provinces in the Inka Empire: Toward a Deeper Understanding of Inka Imperialism. University of Iowa Press, Iowa City.

Molina, Cristóbal de

1959 [1575] Ritos y fábulas de los Incas. Editorial Futuro, Buenos Aires.

Murúa, Fray Martín de

1946 [1590] Historia general del Perú. Ediciones Historia, Madrid.

Ogden, John A.

2006 Skeletal Injury in the Child. Springer, Berlin.

Polo de Ondegardo, Juan

1917 [1571] Informaciones acerca de la religión y gobierno de los Incas. Sanmarti y Ca, Lima.

Previgliano, Carlos. H., Constanza Ceruti, Johan Reinhard, Facundo Arias Araoz, and Josefina G. Diez

2003 Radiologic Evaluation of the Llullaillaco Mummies. American Journal of Roentgenology 181:1473-1479.

Ramos Gavilán, Alonso

1976 [1621] Historia de nuestra señora de Copacabana. Editorial Universo, La Paz, Bolivia.

Reinhard, Johan

2006 The Ice Maiden: Inca Mummies, Mountain Gods, and Sacred Sites in the Andes. National Geographic Books, Washington, DC

Reinhard, Johan, and Constanza Ceruti

2005 Sacred Mountains, Ceremonial Sites, and Human Sacrifice among the Incas. Archaeoastronomy 19:1-43.

Reinhard, Johan, and Constanza Ceruti

2010 Inca Rituals and Sacred Mountains: A Study of the World's Highest Archaeological Sites. Cotsen Institute of Archaeology, University of California, Los Angeles.

Sanhueza, Alvaro, Lizbet Pérez, Jorge Díaz, David Busel, Mario Castro, and Alejandro Pierola

2005 Paleoradiología: Estudio imagenológico del niño del cerro El Plomo. Revista Chilena de Radiología 11 (4): 184-190.

Schaefer, Maureen, Sue Black, and Louise Scheuer

2009 Juvenile Osteology: A Laboratory and Field Manual. Elsevier Academic Press, London.

Schobinger, Juan

1966 La" momia" del cerro El Toro: Investigaciones arqueologicas en la cordillera de la provincia de San Juan (República Argentina). Universidad Nacional de Cuyo, Mendoza, Argentina. 
2001 El santuario incaico del cerro Aconcagua. Universidad Nacional de Cuyo, Mendoza, Argentina.

2003 La momia Inca del Nevado de Chuscha (noroeste Argentino): Resultado preliminar de su estudio. Boletín de Arqueología PUCP 7:277-285.

Socha, Dagmara

2011 Status społeczny w przedhiszpańskich Andach na przykładzie pochówku zbiorowego z Chullpa No. 1 na st. Maucallacta, w południowym Peru. Bachelor's thesis, Department of History, University of Warsaw, Warsaw, Poland.

Szemiński, Jan, and Mariusz Ziółkowski

2006 Mity, rytuały i polityka Inków. Państwowy Instytut Wydawniczy, Warsaw, Poland.

Ubelaker, Douglas

1979 Human Skeletal Remains: Excavation, Analysis and Interpretation. Smithsonian Institution, Washington, DC.

Ulloa Mogollón, Juan de

1965 [1586] Relación de la provincia de los Collaguas. In
Relaciones geográficas de Indias Perú, edited by Marcos Jiménez de la Espada, Vol. 1, pp. 326-333. Ediciones Atlas, Madrid.

Waldron, Tony

2008 Palaeopathology. Cambridge University Press, Cambridge.

Wilson, Andres. S., Emma L. Brown, Chiara Villa, Niels Lynnerup, Andrew Healey, Constanza Ceruti, Johan Reinhard, Carlos H. Previgliano, Facundo Arias Araoz, and Timoty Taylor

2013 Archaeological, Radiological, and Biological Evidence Offer Insight into Inca Child Sacrifice. Proceedings of the National Academy of Sciences of the United States of America 110:13322-13327.

Submitted August 29, 2019; Revised March 11, 2020; Accepted September 18, 2020 